\title{
ДОСЛІДЖЕННЯ ЗНОШЕННЯ КАРБІДОВОЛЬФРАМОВИХ ВАЛКІВ ДРОТОВОГО БЛОКУ
}

Зносостійкість валків, як основного робочого інструменту прокатних станів, у значній мірі визначає рівень виробничих витрат, простої станів, та загальну собівартість продукції. Тому задачі прогнозування зношення, підвищення стійкості, розробки нових валкових матеріалів та забезпечення ефективного використання валків були і залишаються актуальними.

Процеси зношування валків прокатних станів, відповідаючи загальним трибологічним закономірностям, мають свої специфічні особливості. Вивченню таких особливостей присвячені чисельні роботи, в яких наводяться експериментальні та виробничі дані, пропонуються різні моделі для прогнозування зношення валків з різноманітних матеріалів, які свого часу застосовували на прокатних станах [1-3]. Однак, враховуючи розробку та впровадження нових валкових матеріалів, виникає необхідність постійного вивчення і аналізу особливостей зношування валків як 3 матеріалів, які традиційно застосовують на прокатних станах, так і з нових матеріалів $[4,5]$. Одними з таких, відносно нових, матеріалів є тверді сплави на основі карбіду вольфраму. Такі валки забезпечують збільшення зносостійкості валків у декілька разів, але через високу вартість їх застосовування залишається обмеженим. Детальне вивчення особливостей зношення та розробка надійних методів вимірювання зношення дозволить підвищити ефективність застосування твердосплавних валків і розширити області їх використання.

Згідно практичних даних $[6,7]$, для твердосплавних валків сортових та дротових станів виділяють такі основні механізми зношування: абразивний; термічні пошкодження (термічні тріщини, сітка розгару); корозія (трибо-хімічні реакції); адгезійний. В залежності від умов застосування валків може переважати той чи інший механізм зношення. Відповідно, можуть бути впроваджені матеріалознавчі, конструктивні або технологічні заходи 3 збільшення зносостійкості валків.

Для визначення зношення валків застосовують методи прямих вимірів, з застосуванням універсальних засобів вимірювань (штангенциркулі, годинникові індикатори), або методи опосередкованого вимірювання з застосуванням спеціалізованих пристосувань та вимірювальних систем [8]. До непрямих методів вимірювання зношення відносять також оптичні методи, опис одного 3 яких наведено в роботі [9]. Такий метод дозволяє достатньо точно визначати зношення по всьому контуру калібру за рахунок відповідного оптичного збільшення, але використана в ньому оптична система не відноситься до засобів вимірювання, тому можливість його застосування потребує підтвердження.

Метою роботи є обгрунтування можливості застосування оптичного методу вимірювання зношення валків прокатного стану та вивчення особливостей зношення карбідовольфрамових валків дротового блоку.

Дослідження виконано в умовах дротового блоку стану 400/200 ПАТ «Дніпровський металургійний комбінат» при прокатуванні катанки діаметром 5,5 мм 3 низьковуглецевої сталі. Зношення валків визначали застосовуючи оптичну установку (рис. 1), згідно патенту [10]. Технологічні параметри прокатування та величини зношення для одного 3 комплектів валків, наведені в роботі [11]. 


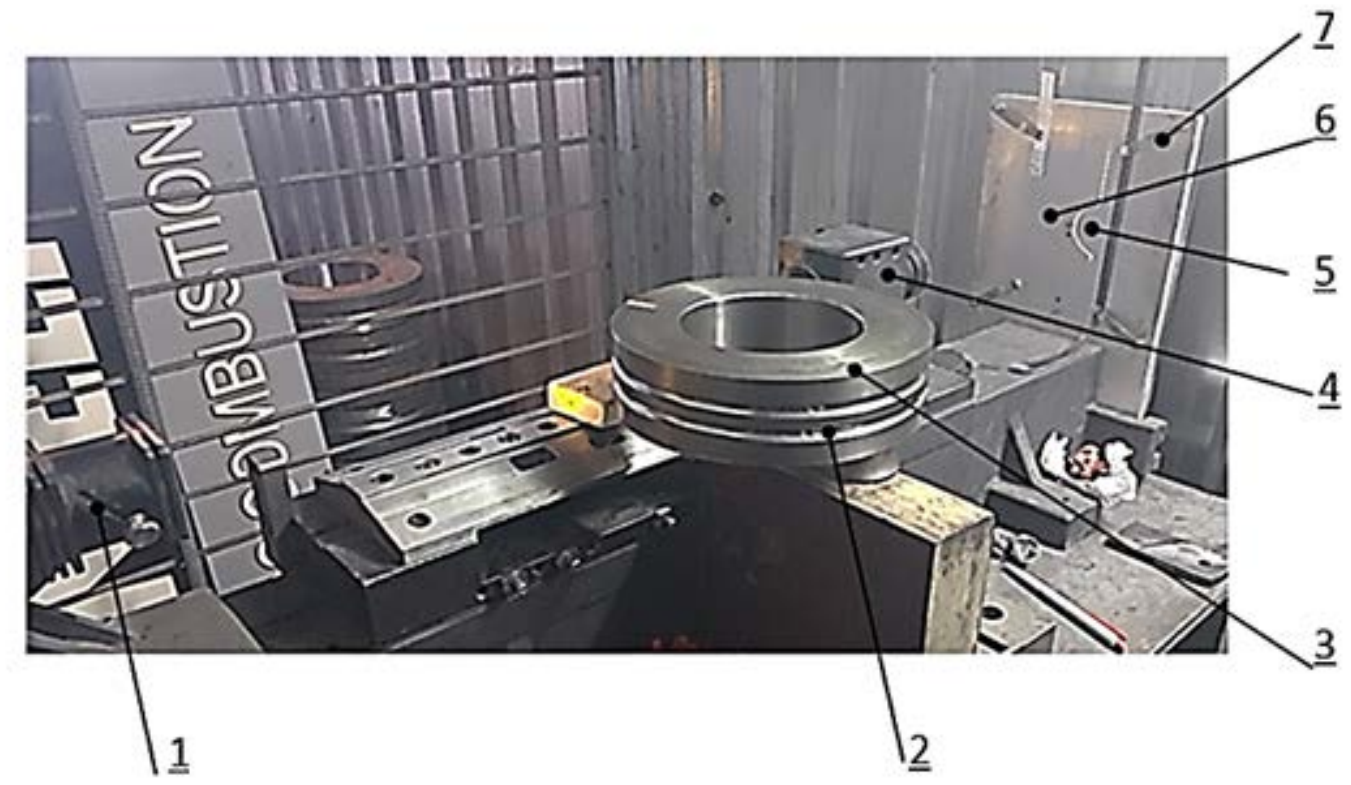
валків:

Рис. 1. Загальний вид оптичної установки, використаної для вимірювань зношення

1 - джерело світла; 2 - вріз валка, зношення якого вимірюється; 3 - валок (шайба); 4 - блок лінз для збільшення зображення; 5 - проекція шаблону; 6 - проекція врізу (ручья) валка; 7 - екран

Дротовий блок стану 400/200, містить десять однотипних модулів, в яких використовують консольно закріплені валки у вигляді шайб (кілець, дисків) номінальним діаметром 210 мм та шириною 72 та 60 мм. Кожен калібр утворюють врізи, відповідної форми, які розміщено в умовно верхньому та нижньому валках. Валки (шайби) виготовляють методами порошкової металургії з зерен карбіду вольфраму та кобальтово-нікелевої зв'язки. Дослідження виконано для валків марки C20C, за класифікацією SANDVIK. Хімічний склад валків марки $\mathrm{C} 20 \mathrm{C}$ : $\mathrm{WC}-80 \%$; $\mathrm{Co}-9 \%$; $\mathrm{Ni}-9 \%$; $\mathrm{Cr}-2 \%$. Фізичні властивості: розмір карбідовольфра-

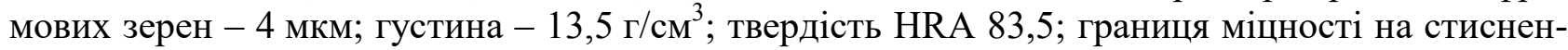
ня 3200 МПа. До особливостей роботи твердосплавних валків дротового блоку відноситься висока швидкість прокатування та висока температура розкату в процесі прокатування, тому їх піддають інтенсивному охолодженню водою.

Валки «чорнових» модулів (М1-М7) мають по два врізи, а валки «чистових» (M8, M9, M10) - по чотири врізи. Відповідно, ці врізи утворюють по два калібри (№ 1 та № 2) в кожному з чорнових модулів та по чотири калібри (№1 - №4) в кожному з чистових. В процесі прокатування використовують один з калібрів кожного з модулів, розміщуючи їх на незмінній лінії прокатування блоку. За одну установку (кампанію роботи) в калібрах чорнових модулів, позначених № 1, здійснено прокатування 2817 т катанки, а в калібрах позначених як № 2 - 2682 т катанки. Для калібрів чистових модулів кількість прокатаного металу становила:

- після калібрів № 1 чорнових модулів: калібри № 1 - 1372 т; калібри № 4 - 1445 м;

-після калібрів № 2 чорнових модулів: калібри № 3 - 1258 т; калібри № 2 - 1425 т.

Методика вимірювань оптичним методом включала розміщення шайб на оптичному стенді між джерелом світла та лінзою, закріплення відповідного шаблону у врізі валка, проектування зазору між шаблоном і зношеною поверхнею врізу валка на екран та фіксацію зображення зазору цифровою камерою (рис. 1). Отримані цифрові фото зображень зазору для кожного з врізів калібру, дозволяють отримати детальну вимірювальну інформацію про зношення валків, зокрема, визначити розподіл зношення по всьому контуру врізу. Тобто, не тільки по осі симетрії врізу, що має місце при застосуванні годинникового індикатору, а по всьому периметру з потрібною деталізацією, наприклад через 1,0 або 0,5мм. Крім цього, 
цифрові фото дозволяють поєднувати зображення зазорів для обох валків, що утворюють калібр (умовно верхнього і нижнього). Оптичний стенд забезпечував шестикратне збільшення. При обробці отриманих зображень зазорів в якості мірила використовували ширину відповідного врізу.

Для оцінки рівня точності оптичного методу виконали багатократні вимірювання величини зношення верхніх врізів валків калібрів № 1 для модулів М4 та М7, які наведені в табл. 1.

Таблиця 1

Результати багатократних вимірів зношення валків модулів M4 та M7 оптичним методом

\begin{tabular}{|c|c|c|c|c|c|c|c|c|}
\hline \multirow[t]{2}{*}{$\begin{array}{l}\text { Номер } \\
\text { виміру }\end{array}$} & \multicolumn{2}{|c|}{$\begin{array}{l}\text { Знос, (мм) для } \\
\text { валків модулів }\end{array}$} & \multirow[t]{2}{*}{$\begin{array}{l}\text { Номер } \\
\text { виміру }\end{array}$} & \multicolumn{2}{|c|}{$\begin{array}{l}\text { Знос, (мм) для } \\
\text { валків модулів }\end{array}$} & \multirow[t]{2}{*}{$\begin{array}{l}\text { Номер } \\
\text { виміру }\end{array}$} & \multicolumn{2}{|c|}{$\begin{array}{l}\text { Знос, (мм) для } \\
\text { валків модулів }\end{array}$} \\
\hline & 4 & 7 & & 4 & 7 & & 4 & 7 \\
\hline 1 & 0,28 & 0,35 & 8 & 0,21 & 0,35 & 15 & 0,22 & 0,37 \\
\hline 2 & 0,25 & 0,36 & 9 & 0,21 & 0,38 & 16 & 0,21 & 0,38 \\
\hline 3 & 0,21 & 0,36 & 10 & 0,22 & 0,41 & 17 & 0,22 & 0,41 \\
\hline 4 & 0,22 & 0,37 & 11 & 0,2 & 0,38 & 18 & 0,21 & 0,41 \\
\hline 5 & 0,21 & 0,42 & 12 & 0,28 & 0,37 & 19 & 0,21 & 0,38 \\
\hline 6 & 0,22 & 0,37 & 13 & 0,25 & 0,4 & 20 & 0,21 & 0,42 \\
\hline 7 & 0,21 & 0,37 & 14 & 0,21 & 0,38 & 21 & 0,2 & 0,36 \\
\hline
\end{tabular}

Для наведених значень отримано наступні статистичні характеристики, відповідно для валків модулів М4 та M7:

- середньоарифметичне

0,222 мм; $0,381 \mathrm{мм}$;

- стандартне відхилення 0,0232 мм; 0,0216 мм;

- інтервал надійності середньоарифметичного 0,0105 мм; 0,0098 мм.

3 аналізу цих статистичних характеристик слідує, що, незважаючи на відмінні значення зношення для круглого і овального калібрів, розміщених, відповідно, у модулях М4 та M7, точність вимірів оптичним методом залишається практично однаковою. Це підтверджується несуттєвою різницею стандартних відхилень (дисперсій) та інтервалів надійності. Отримані значення інтервалів надійності, які визначали за критерієм Стьюдента для рівня значимості $\alpha=0,05$ [12], дозволяють стверджувати, що оптичний метод вимірювання зношення валків забезпечує точність на рівні $\pm 0,01$ мм. Такий рівень точності $є$ цілком прийнятним, як для виробничих умов, так і при проведенні досліджень.

Використовуючи дані вимірювань зношення врізів калібрів № 1 оптичним методом, для валків модулів М1 - М7 та усереднені дані для калібрів № 1 і № 4 модулів M8 - M10, отримали розподілення зношення по модулям блоку, наведене на рис. 2.

Найбільше зношення спостерігається в калібрах модулів М2 та М3. Мінімальне зношення валків чорнових модулів отримали в модулі М6, а для чистових модулів - М10.

Для круглих калібрів спостерігається поступове зменшення зношення до чистового модулю, що обумовлено відповідним зменшенням обсягу зміщуваного металу та зменшенням довжини осередку деформації. При цьому, враховуючи, що валки чистових модулів (М8 та М10) замінюють вдвічі частіше, інтенсивність зношування цих валків одного порядку з інтенсивністю зношення валків модуля М6.

Зношення овальних калібрів суттєво перевищує зношення круглих калібрів, що підтверджено також показниками інтенсивності зношування. Таке перевищення $є$ технологічно обумовлене - коефіцієнти видовження в овальних калібрах завжди перевищують цей же параметр для круглих калібрів. Виявлена значна нерівномірність зношення валків з овальними калібрами пояснюється технологічними особливостями прокатування, до яких відносять виникнення відмінностей в натяжінні розкату між модулями через відхилення в налаштуванні зазорів або невідповідним налаштування привалкової арматури. 


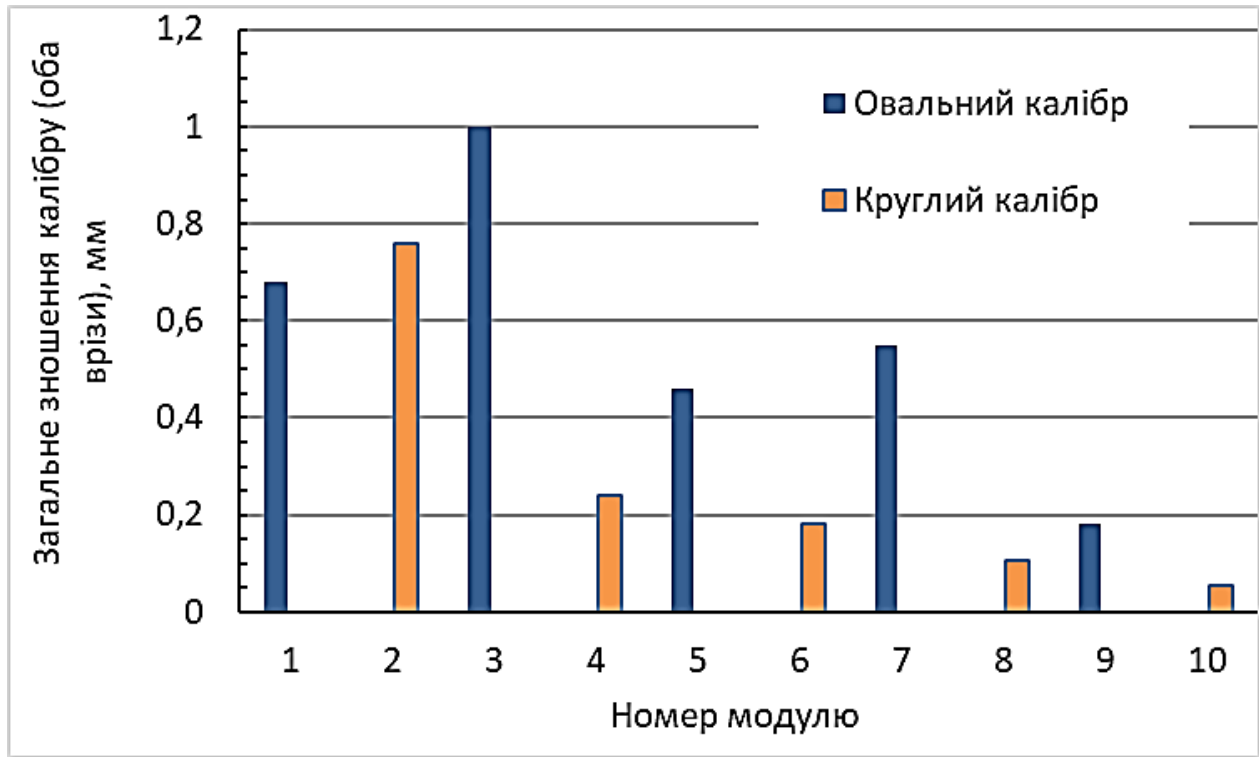

Рис. 2. Розподіл зношення валків по модулям блоку

Отримані дані свідчать про наявність технічної можливості збільшення стійкості овальних калібрів за рахунок забезпечення однакової інтенсивності їх зношення, але це потребує додаткових досліджень з використанням оптичного методу вимірювання зношення.

Згідно отриманих даних, інтенсивність зношення кожного врізу валків, яку визначали як відношення максимальної величини зношення відповідного врізу до маси прокатаного в калібрі металу, для чорнових модулів становить від 0,02 до 0,18 мкм/т (рис. 3). При цьому для врізів овальних калібрів діапазон зміни інтенсивності зношення становить від 0,08 до 0,18 мкм/т, а для врізів круглих калібрів - від 0,02 до 0,15 мкм/т. Для валків чистових модулів інтенсивність зношення становить: для врізів овального калібру 0,08 - 0,1 мкм/т, а для врізів круглих калібрів $0,03-0,08$ мкм/т.

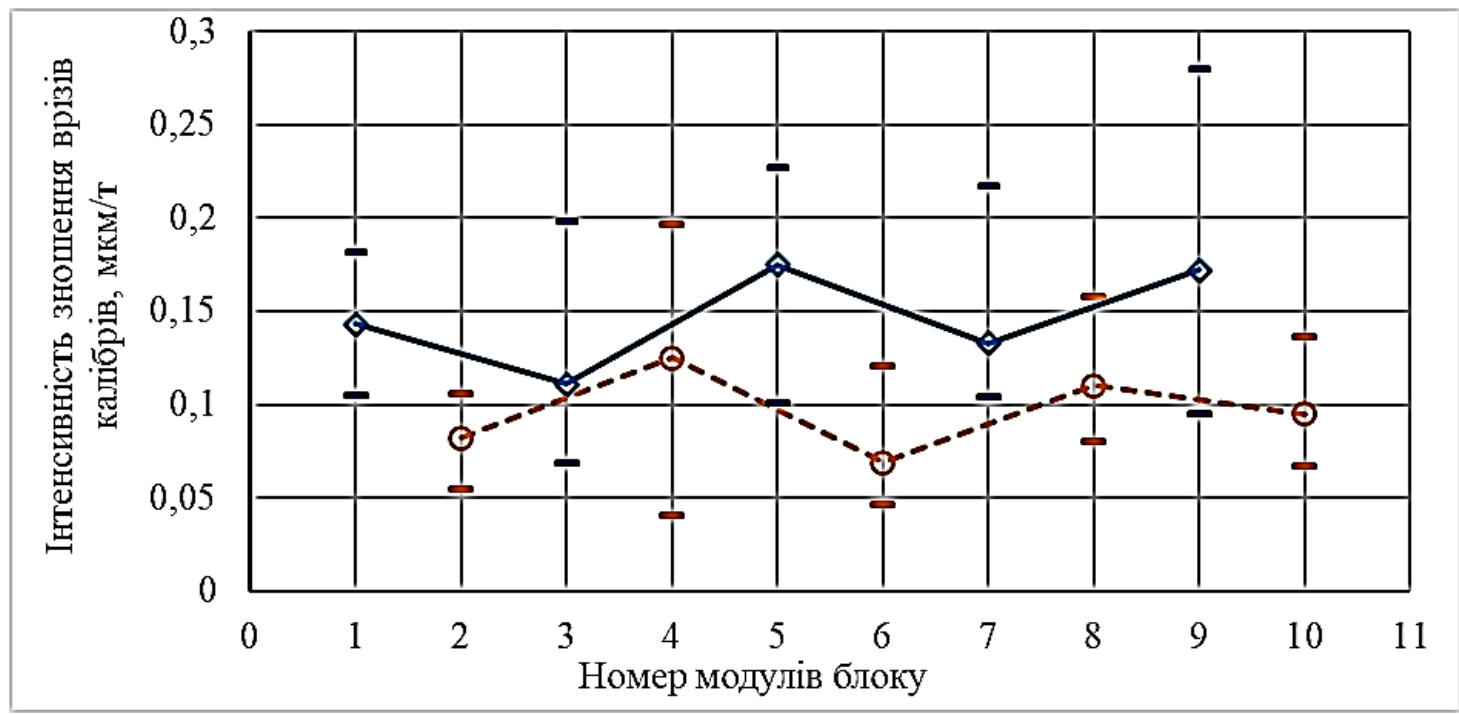

Рис. 3. Інтенсивність зношення врізів калібрів по модулям блоку

Основна перевага оптичного методу вимірювання зношення валків полягає у можливості визначення розподілення зношення по всьому периметру врізів, які утворюють калібр.

Як приклад, на рис. 4 і 5 наведено візуалізацію зазорів між врізами валків та шаблоном, отриману на оптичному стенді. 


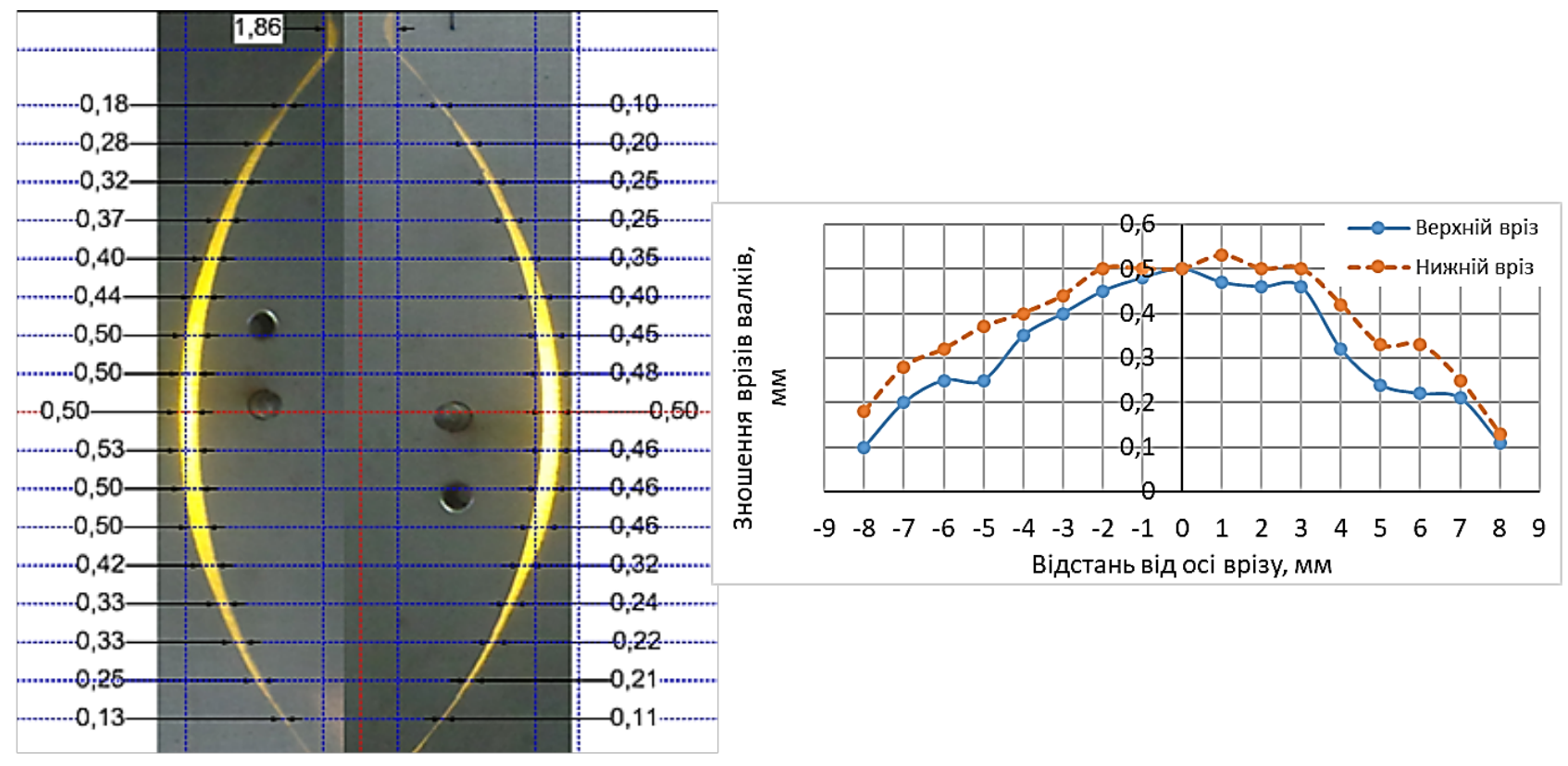

Рис. 4. Зображення зазорів та розподілення зношення по периметру врізів овального калібру № 1 модуля М3
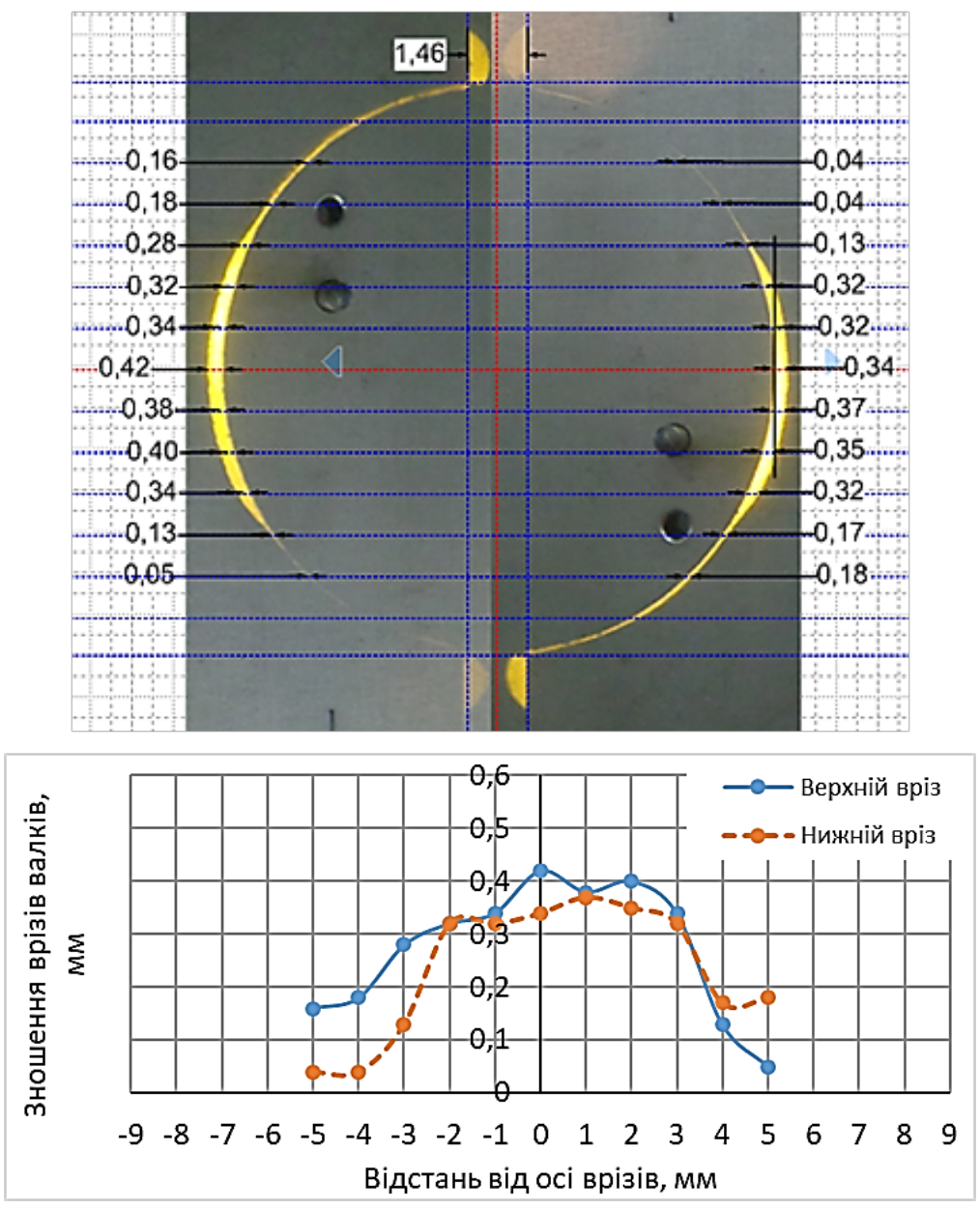

Рис. 5. Зображення зазорів та розподілення зношення по периметру врізів круглого калібру № 1 модуля М2 
На рисунках поєднано зображення зазорів між валками та шаблоном для верхнього та нижнього валків 3 дотриманням дійсних зазорів по буртам валків, які встановлювали при налаштуванні відповідних калібрів, відповідно 1,86 мм для овального калібру, та 1,46 - для круглого. Також на рисунках наведено графічне представлення розподілу зношення по периметру найбільш зношених валків модулів М2 та М3.

3 отриманих даних слідує, що для овальних калібрів характерно рівномірне збільшення зношення від периферії до осі симетрії, а для круглих калібрів - явно виділяється зона інтенсивного зношення зміщена від осі симетрії. Нерівномірність зношення круглих калібрів обумовлена невідповідним налаштуванням вхідної арматури, що призводить до звалювання овального розкату при вході в круглий калібр.

Щодо механізму зношування валків, то для більшості з них переважає адгезійне зношування. Для прикладу, на рис. 6 показана найбільш характерні зношені поверхні калібрів модулів М2 та М3. 3 обох боків від зони інтенсивного зношування спостерігаються зони налипання, де інтенсивність зношування незначна. Очевидно, що така незначна інтенсивність зношування по цим зонам пов'язана 3 приблизною рівновагою між процесами налипання металу та одночасною дією абразивного (стирання) і адгезійного зношування налиплого металу, а також, частково, і поверхні валків.
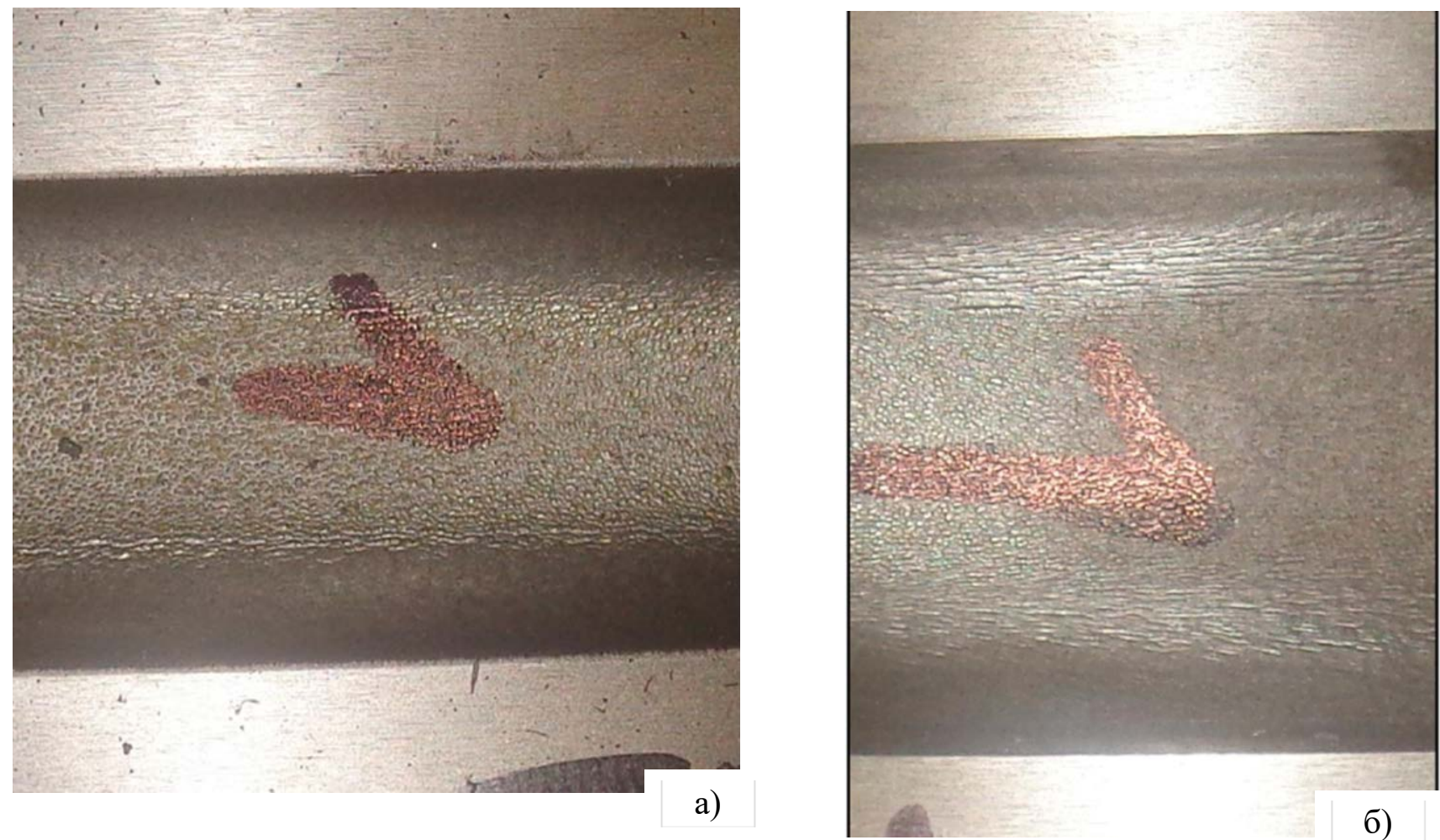

Рис. 6. Поверхня зношених врізів:

а) нижній валок модулю М2, калібр № 1; б) - нижній валок модулю М3, калібр № 1

Аналогічний характер зношування валків має місце і для валків більшості інших модулів. Наприклад, для овального калібру модуля М3 - в осьовій зоні спостерігається наявність як залишків налиплого металу, так і адгезійне зношування, а по бічним зонам більше проявляється налипання металу.

Виключення становлять валки модулів M5 та М6. Як видно з рис. 7, для валків модулю М5 переважає процес налипання металу, а для валків модулю М6 - крім слідів абразивного зношування налиплого металу виділяється сітка розгару у вигляді дрібних тріщин. Очевидно, що характер зношування цих валків за кампанію роботи змінювався. 

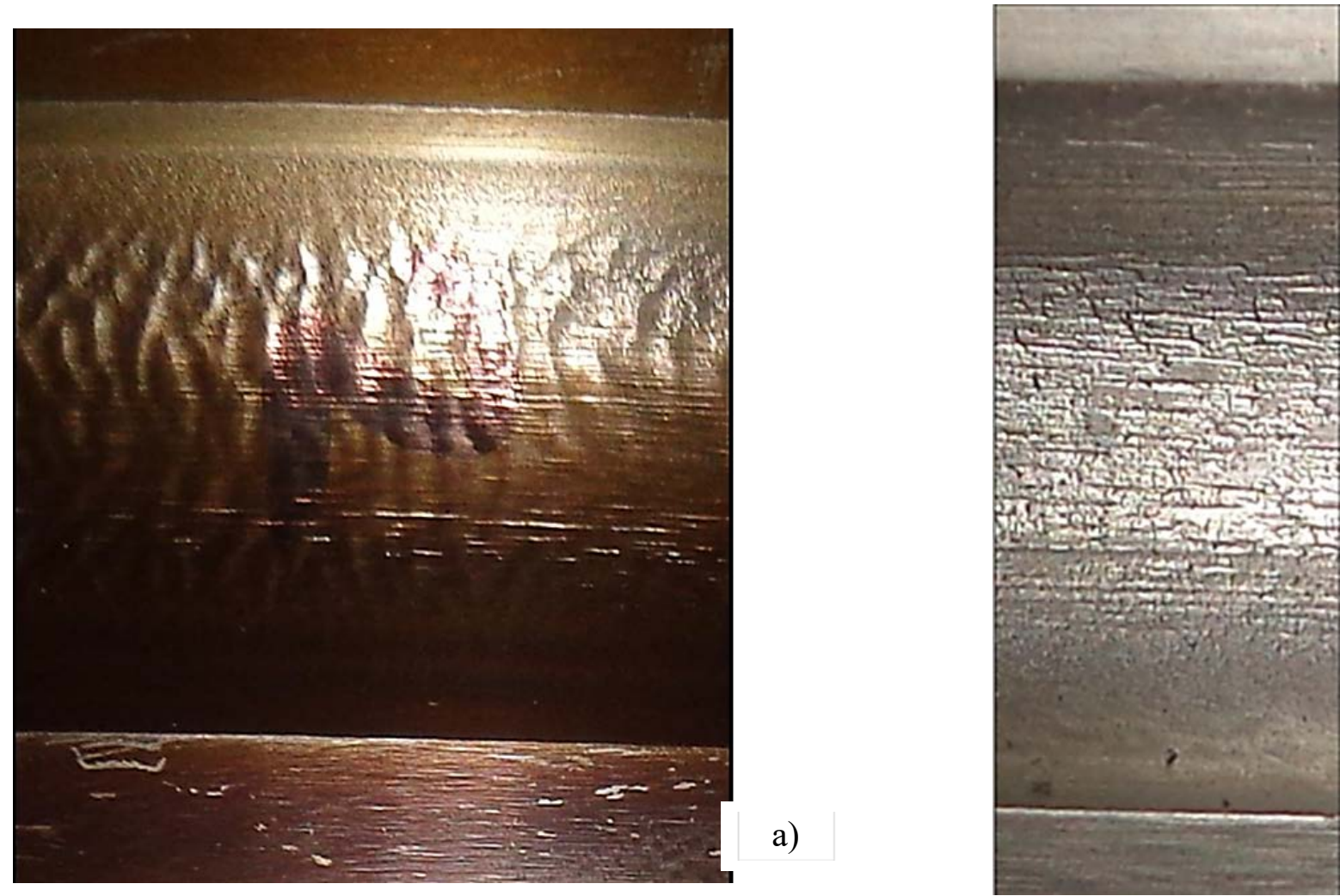

Рис. 7. Поверхня зношених врізів:

а) нижній валок модулю М5, калібр № 2; б) нижній валок модулю М 6, калібр № 1

\section{ВИСНОВКИ}

За результатами статистичної обробки багатократних вимірів зношення врізів карбідовольфрамових валків дротового блоку, які утворюють овальні та круглі калібри, встановлено, що оптичний метод забезпечує точність вимірювань на рівні $\pm 0,01$ мм. Такий рівень точності $\epsilon$ цілком прийнятним для вимірювання зношення валків у виробничих умовах і при проведенні досліджень.

Встановлено, що в силу технологічно обумовлених параметрів в осередку деформації, зношення овальних калібрів перевищує зношення круглих калібрів. Інтенсивність зношення врізів овальних калібрів чорнових модулів становить $0,08-0,18$ мкм/т, а для передчистового модулю М9 - 0,08 - 0,1 мкм/т. Для врізів круглих калібрів інтенсивність зношення становить: для чорнових модулів 0,02-0,15 мкм/т; а для чистових модулів М8 та M10 - 0,03-0,08 мкм/т.

3 аналізу контурів зношення виявлено, що для овальних калібрів у більшості випадків спостерігається рівномірний розподіл зношення відносно осі симетрії калібру. Для круглих калібрів виявлено зміщення максимального зношення від осі симетрії.

3 візуального аналізу зношених поверхонь врізів встановлено, що для твердосплавних валків дротового блоку основними механізмами зношення є поєднання адгезійного налипання металу, який прокатується, та абразивного стирання як налиплого металу, так і валків. Термічні пошкодження та корозія для твердосплавних валків проявляється незначною мірою.

\section{СПИСОК ВИКОРИСТАНОЇ ЛІТЕРАТУРИ}

1. Чекмарев А. П., Машковцев Р. А. Износ прокатных валков. Москва: Металлургиздат, 1955. 148 с.

2. Воронцов Н. М., Жадан В. Т., Шнееров Б. Я. и др. Эксплуатация валков обжимных и сортовых станов. Москва: Металлургия, 1973. 288 с.

3. Северденко В. П., Бахтинов В. Б., Бахтинов Ю. Б. Валки для профильного проката. Москва: Металлургия, 1979. 224 с.

4. Zybill C., Gryany V., Bush J., Myronova O., Romschied M. New graphitized HSS materials for rolls in finishing stands. Stahl und Eisen. 135 (2015). 10, pp. 61-64. 
5. Кирилів В. І., Чайковський Б. П., Максимів О. В. та ін. Роботоздатність валкової сталі 60Х2М з поверхневою наноструктурою. Фізико-хімічна механіка матеріалів. 2016. 52. 6. С. 93-97.

6. Spuzic S., Strafford K.N., Subramanian C., Savage G. Wear of Hot Rolling Mill Rolls: An Overview. WEAR. 1994. 176, pp. 261-271.

7. Turk R., Fajfar P., Robic R., Perus I. Predition of hot strip mill roll wear. Metalurgy, 2002.41 (1), pp. 47 - 51.

8. Byon S.M., Lee Y. Experimental and Semi-analytical Study of Wear Contour of Roll Groove and Its Applications to Roll Mill. ISIJ International. 2007. 47. 7, pp. $1006-1015$.

9. Максименко О. П., Штода М. Н., Марченко К. К., Гляненко О. В. Разработка новой методики изучения износа валков при прокатке в проволочном блоке. Збірник наукових праць Дніпровського державного технічного університету (Машини і пластична деформація металу). 2018. С. 70 - 74.

10. Пат. 138529U Україна. Оптична установка для вимірювання зношення циліндричних деталей з врізами. ДДТУ. 2019.

11. Максименко О. П., Оробцев А. Ю., Самохвал В. М., Штода М. М., Марченко К. К. Методика исследования и анализ износа калибров валков проволочного блока. Обработка материалов давлением. Краматорск: ДГМА. 2019. 1 (48). С. 157-162.

12. Румшиский Л. 3. Математическая обработка результатов эксперимента: Справочное пособие. Москва: Наука, 1976. 192 с.

\section{REFERENCES}

Russian)

1. Chekmarev A.P., Mashkovtsev R.A. Wear rolls of rolling mills. Moscow: Metallurgizdat. 1955. 148 p. (in

2. Vorontsov N.M., Zhadan. B.Ya., Shneyerovich B.J. et al. Operation rolls breakdown and section mills. Moscow: Metallurgy. 1973. 288 p. (in Russian).

3. Severdenko V.P., Bakhtinov Yu.B., Bakhtinov V.B. Rolls for groove rolling. Moscow: Metallurgy. 1979. 224 p. (in Russian).

4. Zybill C., Gryany V., Bush J., Myronova O., Romschied M. New graphitized HSS materials for rolls in finishing stands. Stahl und Eisen. 2015. 135. 10, pp. 61-64.

5. Kyryliv V.I., Chaikovskyi B.P., Maksymiv O.V. and other. Serviceability of roller 60X2M steel with surface nanostructure. Physicochemical mechanics of materials. 2016. 52. 6, pp. 93-97. (in Ukrainian).

6. Spuzic S., Strafford K.N., Subramanian C., Savage G. Wear of Hot Rolling Mill Rolls: An Overview. WEAR. 1994. 176, pp. 261-271. pp. $47-51$.

7. Turk R., Fajfar P., Robic R., Perus I. Prediction of hot strip mill roll wear. Metalurgy, 2002. 41 ( 1),

8. Byon Sang-Min, Lee Youngseog. Experimental and Semi-analytical Study of Wear Contour of Roll Groove and Its Applications to Roll Mill. ISIJ International. 2007. 47. 7, pp. 1006-1015.

9. Maksimenko O.P., Shtoda M.N., Marchenko K.K., Gljanenko O.V. Development new method studying wear of rolls during rolling in wire block. Bulletin of Dniprovsk State Technical University (Machines and plastic deformation of metal). 2018, pp. 70-74. (in Russian). 2019.

10. Pat. 138529 Ukraine. Optical installation for measuring wear of cylindrical parts with grooves. DSTU.

11. Maksymenko O.P., Orobtsev A.Yu., Samokhval V.M., Shtoda M.M., Marchenko K.K. Methods of research and analysis of wear gauges rolls wire block. Materials Working by Pressure. 20 19. 1 (48), pp. 157-162. (in Russian).

12. Rumshiskiy L.Z. Mathematical processing of experimental results: Reference book. Moscow: Nauka, 1976. 192 p. (in Russian).

Максименко О. П. - д-р. техн. наук, проф., зав. каф. ОМТ ДДТУ;

E-mail: omd@dstu.dp.ua

Самохвал В. М. - канд. техн. наук, доц. каф. ОМТ ДДТУ;

E-mail: volsamokhval@gmail.com

Марченко К. К. $\quad$ - аспірант каф. ОМТ ДДТУ.

ДДТУ - Дніпровський державний технічний університет, м. Кам’янське. 